\title{
可循环金属铋配合物催化对亚甲基苯醌化合物的 1,6-共轭加成反应研究
}

\author{
李翰林 $a$ \\ 刘冬兰 $a$ 陈 梁 $a$ \\ 许海燕*,a \\ 陆鸿飞*,a \\ (江苏科技大学环境与化学工程学院 江苏镇江 212100)
}

\begin{abstract}
摘要 设计并合成了一种可催化对亚甲基苯醌化合物的 1,6-加成反应的金属铋络合物，并得到二芳基及其取代化合物. 该反应的显著特征是使用了廉价、未开发、未引起重视和可重复利用的金属铋络合物，使反应更具有可持续性. 另外 二芳基甲基取代化合物产率高、底物范围广、官能团耐受性好，反应操作简便、条件温和，是一种可行性高且有吸引 力的方案.
\end{abstract}

关键词 亚甲基苯醌化合物; 铋催化; 1,6-加成

\section{Alkoxylation of para-Quinone Methides via Bismuth Complex Catalyzed 1,6-Addition Reactions of Alcohols}

\author{
Li, Hanlin ${ }^{a}$ Liu, Donglan ${ }^{a}$ Chen, Liang ${ }^{a} \quad$ Xu, Haiyan ${ }^{*, a}$ Lu, Hongfei ${ }^{*, a}$ \\ (School of Environmental and Chemical Engineering, Jiangsu University of Science and Techonology, Zhenjiang 212100)
}

\begin{abstract}
An effective 1,6-addition route for para-quinone methides (p-QMs) to synthesize bismuth-catalyzed substituted diarylmethanes was developed. The key feature of this transformation in our methodology is that the metallic bismuth complexes are inexpensive, untapped, overlooked, and reusable, making the reaction more sustainable. Moreover, this protocol provides facile access to a class of deviratives of diaryl and triarylmenthanes with good to excellent yields and good tolerance of the functional groups. A feasible and appealing solution is delivered by convenient work-up and mild reaction conditions.
\end{abstract}

Keywords $p$-QMs; bismuth-catalysis; 1,6-addition

\section{Introduction}

Because of the omnipresence structural characteristics, para-quinone methides ( $p$-QMs) have been widely studied as an essential and readily accessible class of synthetic intermediates ${ }^{[1]}$ present in a wide variety of biologically active natural products. ${ }^{[2]}$ In the past decades, $p$-QMs have been proved to be an excellent 1,6-Michael acceptor for the construction of a broad range of 2,4,6-trisubstituted phenols (or) substituted triarylmethane derivatives. ${ }^{[3]} \mathrm{On}$ the one hand, 1,6-Michael addition is one of the most successful and atom-economic methods to produce a variety of structurally complex diarylmethane compounds with great practical value, beginning from raw materials, as a routine protocol. The asymmetric 1,6-conjugate addition/ aromatization of $p$-QMs for enantioselective construction of functionalized diarylmethane derivatives was recently stated by Fan and coworkers. ${ }^{[4]}$ The asymmetric synthesis of diarylmethane derivatives was then independently de- veloped by Jørgensen, ${ }^{[5]}$ Liao, ${ }^{[6]}$ Cheng, ${ }^{[7]}$ Tortosa $,{ }^{[8]} \mathrm{Lu},{ }^{[9]}$ Deng, ${ }^{[10]} \mathrm{Li}^{[11]} \mathrm{Xu}^{[12]}$ and Enders ${ }^{[13]}$ through the addition of 1,6-Michael $p$-QMs, which act as the flexible synthetic scaffold. However, all these approaches and catalysts used, have limited substrates scope and are difficult to recycle.

On the other hand, the production of green and straightforward synthetic strategy to obtain multi-substituted diarylmethane derivatives in synthetic chemistry is of growing fundamental interest. As consequence, it is still highly desirable to develop novel synthetic methodology for the preparation of diarylmethane derivatives using $p$-QMs. Therefore, considerable attention has been given to the synthesis of highly effective strategies for the synthesis of diaryl and triarylmethane derivatives in a green way via 1,6-conjugate addition of $p$-QMs. ${ }^{[14]}$ Most recently, the Mei group ${ }^{[15]}$ established a practical protocol for the synthesis of various diarylmethane derivatives from $p$-QMs and alcohol/thiol through 1,6-Machael addition reaction. In terms of good functional-group compatibility and wide

* Corresponding authors. E-mail: zjluhf1979@just.edu.cn; xuhaiyanjurong@163.com
Received March 8,2021; revised April 25,2021; published online June 1, 2021. 
substrate scope, the reaction shows superior performance.

Furthermore, bismuth is recognized as a low-cost, environmentally benign, easy-to-handle metal, and its bismuth (III) salts have been commonly used as Lewis acid catalysts. Recently, in order to synthesize diphenylmethane derivatives, the $\mathrm{Li}$ group reported $\mathrm{Bi}(\mathrm{OTf})_{3}$ catalyzed 1,6-conjugate addition of $p$-QMs with 3-propenyl-2-silyloxyindoles and allylboronic acid pinacol ester. ${ }^{[16 a]} \mathrm{Bi}(\mathrm{OTf})_{3}$ catalyzed intermolecular 1,6-hydroolefination of $p$-QMs with styrenes was reported by the Anand group. ${ }^{[16 b]}$ However, isolation and recycle of $\mathrm{Bi}(\mathrm{OTf})_{3}$ catalyst from the reaction mixture are challenge tasks. Our group have developed a new heterogeneous bismuth complex formed by $\mathrm{BiCl}_{3}$ and piperazine, which was further characterized and used as an effective and recyclable catalyst for threecomponent Mannich, ${ }^{[17]}$ and ring opening of epoxides reactions. ${ }^{[18]}$ It is worth to note that this bismuth complex is easy to prepare and bench stable. Related bismuth complex $\left\{\left(\mathrm{C}_{5} \mathrm{H}_{6} \mathrm{~N}_{4} \mathrm{O}\right)\left(\mathrm{C}_{5} \mathrm{H}_{4} \mathrm{~N}_{4} \mathrm{O}\right)_{3}\left(\mathrm{C}_{5} \mathrm{H}_{4} \mathrm{~N}_{4} \mathrm{O}\right)\left(\mathrm{Bi}_{2} \mathrm{Cl}_{11}\right) \mathrm{Cl}_{2}\right\}$ has also been designed and successfully applied in the one pot three-component Biginelli reaction. ${ }^{[19]}$

We also used a bismuth catalyst and a carbon nucleophile in our previous work. ${ }^{[20]}$ In methylene chloride, the sulfur nucleophile reacted with $p$-quinone methides compounds to synthesize a sequence of derivatives of diaryl and triaryl methane. However, under the same conditions, oxygen nucleophiles show no reactivity in the reaction (Scheme 1a). In 2020, Mei's research group ${ }^{[15]}$ used $\mathrm{UO}_{2}$ $\left(\mathrm{NO}_{3}\right)_{2} \bullet 6 \mathrm{H}_{2} \mathrm{O}$ as a catalyst for the first time to perform a 1,6-addition reaction between oxygen nucleophiles and $p$-quinone methides ( $p$-QMs), and obtained a series of diarylmethane derivatives. One of the main drawbacks of this method is that metallic uranium is a poisonous, radioactive material. In this work, we use metal bismuth complexes to catalyze this 1,6-addition reaction (Scheme 1b). To our surprise, we reveal that in the 1,6-conjugate addition of $p$-QMs under moderate reaction conditions, the air-stable and recoverable bismuth complex $\left\{\left(\mathrm{C}_{4} \mathrm{H}_{12} \mathrm{~N}_{2}\right)_{2}\left[\mathrm{BiCl}_{6}\right] \mathrm{Cl} \bullet\right.$ $\left.\mathrm{H}_{2} \mathrm{O}\right\}$ demonstrated high catalytic activities. This methodology was compatible with several functional nucleophiles and provided good to excellent yields for the corresponding products. Particularly, this new bismuth complex can be recycled six times through simple isolation processes and without decreasing catalytic activity. Herein, we present the report on a bismuth-catalyzed 1,6-addition of $p$-QMs to synthesize diaryl and triarylmethane derivatives.

\section{Results and discussion}

In our study, the reaction between $p$-QMs and methanol was used as a template reaction to optimize the conditions. As shown in Table 1, no reaction occurred in the template reaction in the absence of catalyst. The addition of 10 $\mathrm{mol} \%\left(\mathrm{C}_{4} \mathrm{H}_{12} \mathrm{~N}_{2}\right)_{2}\left[\mathrm{BiCl}_{6}\right] \mathrm{Cl} \cdot \mathrm{H}_{2} \mathrm{O}$ (Figures 1 and 2) can effectively promote the reaction, and the reaction completed a) Previous work

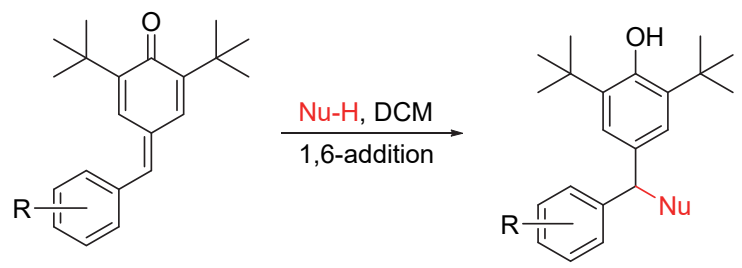

$\mathrm{Nu}=$ malononitrile, dimethyl malonate, $\beta$-keto acid and thiophenol

b) This work<smiles>[R][I-]c1ccc(C=C2C=C(C(C)(C)C)C(=O)C(C(C)(C)C)=C2)cc1</smiles>

$\underset{\substack{\text { [Bi], MeCN } \\ \text { 1,6-addition }}}{\stackrel{\mathrm{R}^{1} \mathrm{OH}}{\longrightarrow}}$<smiles>[R]OC(c1cc[R]([H])cc1)c1cc(C(C)(C)C)c(O)c(C(C)(C)C)c1</smiles>

Scheme 1 1,6-Addition of $p$-QMs catalyzed by [Bi]

$$
\left[\underset{+}{\mathrm{H}_{2} \mathrm{~N}^{+}}\right]_{2}^{\mathrm{NH}_{2}} \cdot\left[\begin{array}{c}
\stackrel{\mathrm{Cl}}{\mathrm{Cl}} / \mathrm{Cl} \\
\mathrm{Cl}_{\mathrm{Cl}}^{\prime}
\end{array}\right]^{3-} \cdot \mathrm{Cl}^{-} \cdot \mathrm{H}_{2} \mathrm{O}
$$

Figure 1 Chemical formula of $\left(\mathrm{C}_{4} \mathrm{H}_{12} \mathrm{~N}_{2}\right)_{2}\left[\mathrm{BiCl}_{6}\right] \mathrm{Cl} \cdot \mathrm{H}_{2} \mathrm{O}$

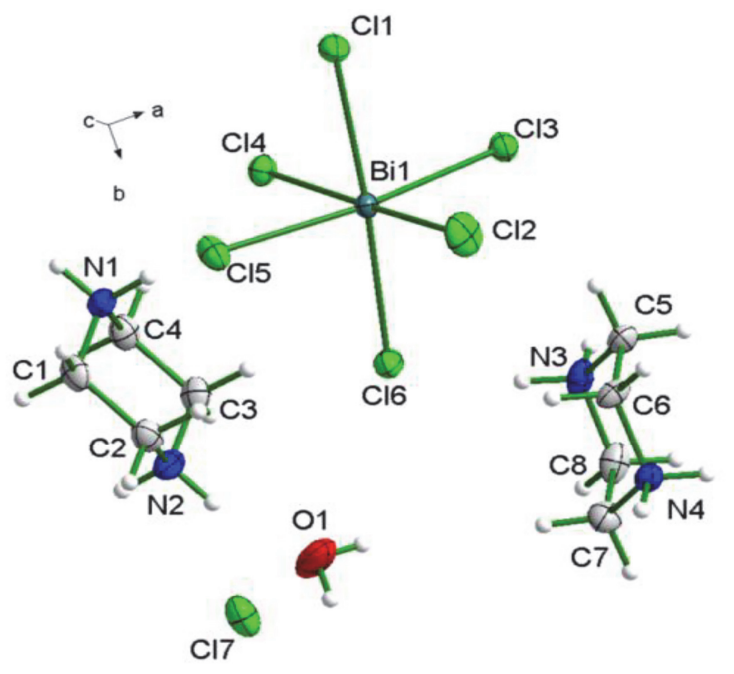

Figure 2 Crystal molecular structure of $\left(\mathrm{C}_{4} \mathrm{H}_{12} \mathrm{~N}_{2}\right)_{2}\left[\mathrm{BiCl}_{6}\right] \mathrm{Cl}$ • $\mathrm{H}_{2} \mathrm{O}$

within $12 \mathrm{~h}$, furnishing the desired product in $98 \%$ yield. Some other bismuth salts, such as $\mathrm{BiCl}_{3}$ and $\mathrm{Bi}(\mathrm{OTf})_{3}$ were screened, giving 3 aa in $75 \%$ and $85 \%$ yields under the same conditions, respectively. In addition, $\mathrm{AlCl}_{3}, \mathrm{FeCl}_{3}$, $\mathrm{Zn}(\mathrm{OTf})_{2}$, Ni- $(\mathrm{OTf})_{2}, \mathrm{Sc}(\mathrm{OTf})_{3}$ were also screened, and the yield was not very satisfactory. The solvent effect on the reaction was examined. Methanol, 1,4-dioxane, toluene, and dichloromethane were screened, and the desired substituted methane 3aa can be observed in trace amount in 1,4-dioxane, toluene, or dichloromethane. On comparison, the yield of $\mathbf{3 a a}$ in methanol is $79 \%$. Furthermore, the catalyst was reduced loading to 1 and $5 \mathrm{~mol} \%$, and the 
yields dropped to $34 \%$ and $72 \%$, respectively. Finally, the reaction was performed in acetonitrile under room temperature in the presence of $10 \mathrm{~mol} \%\left(\mathrm{C}_{4} \mathrm{H}_{12} \mathrm{~N}_{2}\right)_{2}\left[\mathrm{BiCl}_{6}\right] \mathrm{Cl} \cdot$ $\mathrm{H}_{2} \mathrm{O}$.

Table 1 Optimization of reaction conditions
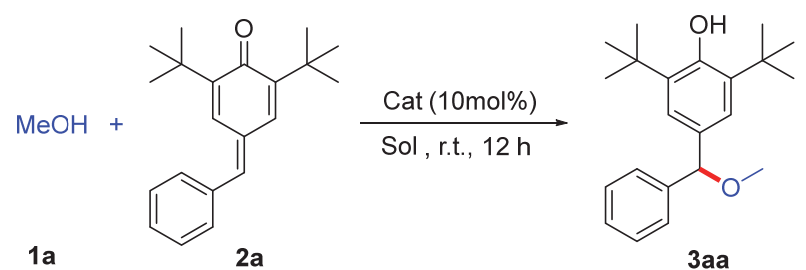

\begin{tabular}{clcc}
\hline Entry & Catalyst $(\mathrm{mol} \%)$ & Solvent & Yield $^{b} \%$ \\
\hline 1 & - & $\mathrm{MeCN}$ & 0 \\
$2^{c}$ & {$[\mathrm{Bi}](10)$} & $\mathrm{MeCN}$ & 98 \\
3 & $\mathrm{BiCl}_{3}(10)$ & $\mathrm{MeCN}$ & 75 \\
4 & $\mathrm{Bi}(\mathrm{OTf})_{3}(10)$ & $\mathrm{MeCN}$ & 84 \\
5 & $\mathrm{FeCl}_{3}(10)$ & $\mathrm{MeCN}$ & 53 \\
6 & $\mathrm{AlCl}_{3}(10)$ & $\mathrm{MeCN}$ & 58 \\
7 & $\mathrm{Zn}(\mathrm{OTf})_{2}(10)$ & $\mathrm{MeCN}$ & 63 \\
8 & $\mathrm{Ni}(\mathrm{OTf})_{2}(10)$ & $\mathrm{MeCN}$ & 65 \\
9 & $\mathrm{Sc}(\mathrm{OTf})_{3}(10)$ & $\mathrm{MeCN}$ & 50 \\
10 & {$[\mathrm{Bi}](10)$} & $\mathrm{MeOH}$ & 79 \\
11 & {$[\mathrm{Bi}](10)$} & $1,4-\mathrm{Dioxane}$ & Trace \\
12 & {$[\mathrm{Bi}](10)$} & Toluene & Trace \\
13 & {$[\mathrm{Bi}](10)$} & $\mathrm{DCM}$ & Trace \\
14 & {$[\mathrm{Bi}](1)$} & $\mathrm{MeOH}$ & 34 \\
15 & {$[\mathrm{Bi}](5)$} & $\mathrm{MeOH}$ & 72 \\
\hline
\end{tabular}

${ }^{a}$ Reaction conditions: $p$-QM (2a) $(0.25 \mathrm{mmol})$, methanol (1a) $(1.25 \mathrm{mmol})$, solvent $(2 \mathrm{~mL}) ;{ }^{b}$ The separation yield based on $p$-QMs as a limiting reagent; ${ }^{c}$ Bismuth complex [Bi] refers to $\left(\mathrm{C}_{4} \mathrm{H}_{12} \mathrm{~N}_{2}\right)_{2}\left[\mathrm{BiCl}_{6}\right] \mathrm{Cl} \cdot \mathrm{H}_{2} \mathrm{O}$.

Under optimized reaction conditions, the substrate range of $p$-QMs and the universality of the scheme were further explored. As shown in Table 2, a large number of $p$-QMs can be tolerated and the corresponding diarylmethane products are given with moderate to excellent yields. The electron-rich (4-Me, 3-Me, 4-OMe, 3-OMe) aryl substituents are suitable substrates, and the corresponding diarylmethane products 3ab $\sim \mathbf{3 a d}$ are obtained in yields of $64 \% \sim 78 \%$. The reaction process is also suitable for halogen functional groups, and the products $\mathbf{3 a e} \sim \mathbf{3}$ ah can be obtained with high yields $(65 \% \sim 96 \%)$. When the paraposition is an electron withdrawing group such as $(\mathrm{CN}$, $\mathrm{NO}_{2}$ ), the corresponding target molecules 3ai $~ 3 a k$ can be obtained in modrate to excellent yields $(75 \% \sim 98 \%)$. The naphthalene-substituted product 3al can be obtained in $85 \%$ yield. Besides aryl-substituted $p$-QMs, hetero-arylsubstituted $p$-QM $\mathbf{2 m}$ is also a reactive substrate for this transformation with a dcreasing yield (58\%).

For further investigation, a series of alcohols were introduced that reacted with $p$-QMs through 1,6-Michael addition to afford different functionalities. As shown in Table 3, under the standard conditions, all desired products can be obtained in moderate yields. The results imply that the effects of both steric hindrance and electronic proper-
Table 2 Substrate scope of $p-\mathrm{QMs}$
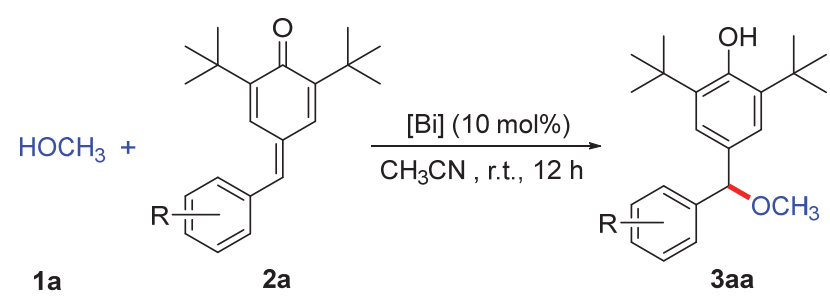

\begin{tabular}{|c|c|c|}
\hline Compd. & $\mathrm{R}$ & Yield $^{b} / \%$ \\
\hline $3 \mathbf{a a}$ & 4-H & 98 \\
\hline $3 \mathbf{a b}$ & 4-Me & 75 \\
\hline $3 a c$ & 3-Me & 78 \\
\hline 3ad & 3,5-Me & 74 \\
\hline $3 a e$ & $4-F$ & 65 \\
\hline 3af & $4-\mathrm{Cl}$ & 80 \\
\hline $3 a g$ & $4-\mathrm{Br}$ & 76 \\
\hline $3 a h$ & $2-\mathrm{Cl}$ & 96 \\
\hline 3ai & $4-\mathrm{CN}$ & 98 \\
\hline 3aj & $4-\mathrm{NO}_{2}$ & 98 \\
\hline 3ak & $4-\mathrm{CF}_{3}$ & 75 \\
\hline 3al & & 85 \\
\hline 3am & & 58 \\
\hline
\end{tabular}

${ }^{a}$ Reaction conditions: methanol (1a) $(1.25 \mathrm{mmol}), p$-QMs (2) $(0.25 \mathrm{mmol})$, solvent $(2 \mathrm{~mL}) .{ }^{b}$ The separation yield based on $p$-QMs as a limiting reagent. ${ }^{c}$ Bismuth complex [Bi] refers to $\left(\mathrm{C}_{4} \mathrm{H}_{12} \mathrm{~N}_{2}\right)_{2}\left[\mathrm{BiCl}_{6}\right] \mathrm{Cl} \cdot \mathrm{H}_{2} \mathrm{O}$.

ties have little influence on the reactivity.

In the aim of surveying more utilities of this synthetic methodology, the synthesis of gram-scale 2,6-di-tert-butylbenzoquinone was also conducted. Under standard conditions, the reaction can provide the target molecule $\mathbf{3 a}$ in maintained yield (19, 90\%) in Scheme 2. The substance as a pharmacologically active molecule is ubiquitous in natural products and in biology and biology. ${ }^{[21]}$ Therefore, the established method is effective for the synthesis of di-methane derivatives with potential biological activity.

In order to verify the high efficiency and reusability of the catalyst, we tried to separate the catalyst from the reaction system and reused it. Under the optimal reaction conditions described in Table 1, the 1,6-conjugated addition reaction of $p$-QM (2a) and methanol (1a) was studied using [Bi] complex as a catalyst. The [Bi] catalyst can be recovered only through a simple filtration step, and then washed with acetonitrile and dried after the reaction is completed. As shown in Figure 1, the recovered catalyst can be reused without further treatment, and in the six-cycle test (with a yield of up to $90 \%$ ), there is no change in catalytic activity (Figure 3 ). 
Table 3 Substrate scope of alcohols

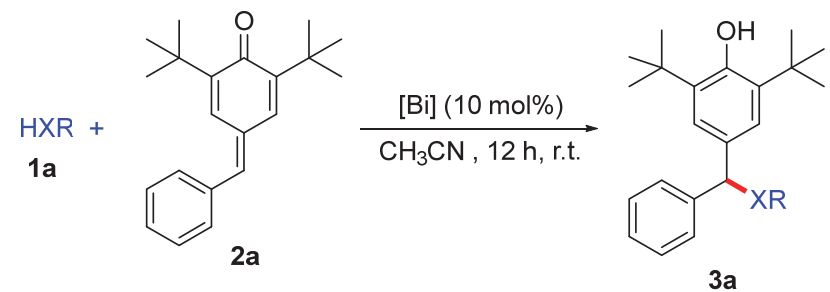

$3 a$

\begin{tabular}{clc}
\hline Compd. & \multicolumn{1}{c}{$\mathrm{R}$} & Yield $/$ o\% \\
\hline 3aa & $\mathrm{OMe}$ & 98 \\
3ba & $\mathrm{OEt}$ & 96 \\
3ca & $\mathrm{OCH}_{(\mathrm{CH})_{3}}$ & 60 \\
3da & $\mathrm{OCH}_{2} \mathrm{CH}_{2} \mathrm{CH}_{2} \mathrm{CH}_{3}$ & 73 \\
3ea & & \\
3fa &
\end{tabular}

${ }^{a}$ Reaction conditions: $p$-QM (2a) $(0.25 \mathrm{mmol})$, alcohol (1) $(1.25 \mathrm{mmol})$, solvent $(2 \mathrm{~mL}) .{ }^{b}$ The separation yield based on $p$-QMs as a limiting reagent. ${ }^{c}$ Bismuth complex [Bi] refers to $\left(\mathrm{C}_{4} \mathrm{H}_{12} \mathrm{~N}_{2}\right)_{2}\left[\mathrm{BiCl}_{6}\right] \mathrm{Cl} \cdot \mathrm{H}_{2} \mathrm{O}$.

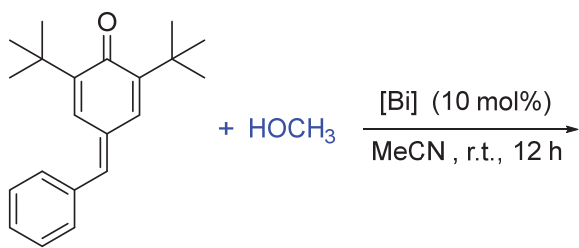

$1 \mathrm{~g}, 3.4 \mathrm{mmol}$

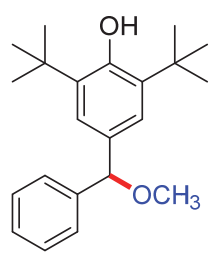

$1.08 \mathrm{~g}, 3.3 \mathrm{mmol}$
Scheme 2 Scale synthesis of 2,6-di-tert-butyl-4-(methoxy(phenyl)methyl)phenol

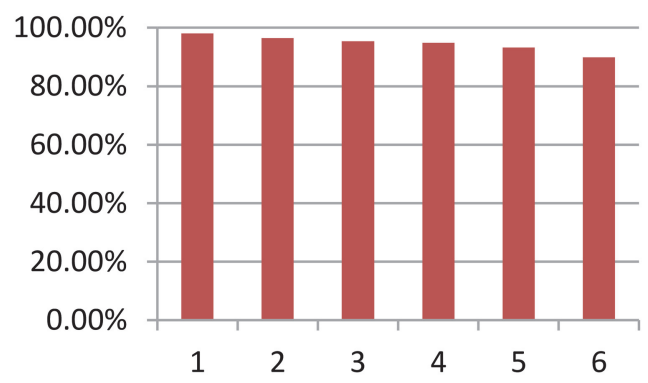

Figure 3 Catalyst recycling yield chart

Based on the experimental results above and literature reports, ${ }^{[22-23]}$, the possible mechanistic pathway of the 1,6-Michael addition reaction of $p$-QMs and alcohol catalyzed by [Bi] is illustrated in Scheme 3. Firstly, the [Bi] occupied the coordination site on the oxygen atom of substrate 2a via chelated transition state $\mathbf{A}$. Then, the ketone oxygen position of species $\mathbf{A}$ coordinated with proton and the interaction enabled the molecular polarization followed by aromatization, and would afford the intermediate $\mathbf{B}$ with more electropositive feature. Next, the resulting species B underwent intermolecular typical nucleophilic addition reaction by methanol 1a to give $\mathbf{C}$. Finally, deprotonation of $\mathbf{C}$ occurred, affording the target product 3aa with regenerating the $[\mathrm{Bi}]$ catalyst.

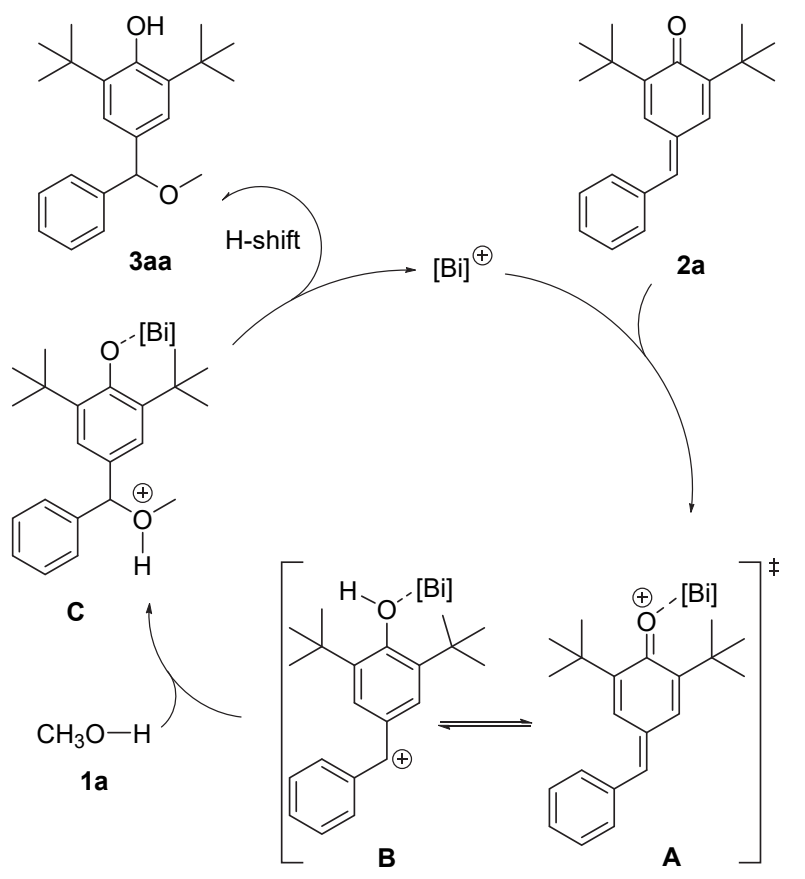

Scheme 3 Possible mechanistic pathway

\section{Conclusions}

In summary, we have explored a highly effective method for the synthesis of diaryl and triarylmethane derivatives through bismuth complex catalyzed 1,6-conjugate addition of commonly utilized nucleophiles to $p$-QMs. Broad substrate scope, high product yields and atomic economy are the major tenets of this protocol. In addition, the bismuth complex is non-toxic, air-stable and can also be successfully recycled as a catalyst several times. In our laboratory, further experiments are ongoing, including the construction of novel chiral bismuth complexes and an asymmetric version.

\section{Experimental section}

\subsection{Instruments and reagents}

Unless otherwise noted, all reagents were purchased from commercial sources (Adamas, Energy, Aldrich) and used as received without further purification. The liquid ${ }^{1} \mathrm{H}$ spectra were recorded on a Bruker-Avance DPX $400 \mathrm{MHz}$ spectrometer using the solvent $\mathrm{CDCl}_{3}$. Chemical shifts were reported and the residual solvent peak was used as an internal reference: proton (chloroform $\delta$ 7.26), carbon (chloroform $\delta$ 77.16). Mass spectral data (MS) was recorded using an Agilent-6110 mass spectrometer. For thin layer chromatography (TLC), pre-coated Qingdao Haiyang 
TLC plates (GF254) were used, and compounds were visualized with a UV light at $254 \mathrm{~nm}$. Flash chromatographic separations were performed on 200 300 mesh silica gel (from Qingdao Haiyang Chem. Company, Ltd.).

\subsection{General procedure for the synthesis of the bis-} muth complexes

In a $50 \mathrm{~mL}$ beaker, piperazine $(0.005 \mathrm{~mol}, 0.43 \mathrm{~g}), \mathrm{BiCl}_{3}$ $(0.0034 \mathrm{~mol}, 1.075 \mathrm{~g}), 35 \% \mathrm{HCl}(2 \mathrm{~mL})$ and water $(20 \mathrm{~mL})$ were added in sequence, and the reaction mixture was stirred and heated to $80{ }^{\circ} \mathrm{C}$ until all the solids were dissolved. Then, the temperature of the solution was slowly lowered to room temperature, and the solution was allowed to stand still. After a few days, white crystals of long rice grains were obtained.

\subsection{General procedure for the synthesis of the 3aa}

p-QM (1a) (73.6 mg, $0.25 \mathrm{mmol})$, methanol (2a) (40 $\mathrm{mg}, 1.25 \mathrm{mmol})$, [Bi] (16.25 mg, $0.025 \mathrm{mmol})$ were placed in a $10 \mathrm{~mL}$ reaction vessel. An acetonitrile solution $(2 \mathrm{~mL})$ was added to the vessel, and the reaction was stirred at room temperature for $12 \mathrm{~h}$. The solvent was removed in vacuo, and the residue was purified by flash chromatography on silica gel using petroleum ether/ethyl acetate $(V: V=50: 1)$ as the eluent to obtain 2,6-di-tert-butyl-4(methoxy(phenyl)methyl)phenol (3aa $)^{[15]}$ (79.99 mg, 98\% yield) as a white solid. m.p. 96 98 ${ }^{\circ} \mathrm{C}$ (Lit. ${ }^{[15]} 96 \sim$ $98{ }^{\circ} \mathrm{C}$ ); ${ }^{1} \mathrm{H}$ NMR (400 MHz, Chloroform-d) $\delta: 7.39 \sim 7.30$ $(\mathrm{m}, 4 \mathrm{H}), 7.24(\mathrm{~d}, J=7.2 \mathrm{~Hz}, 1 \mathrm{H}), 7.11(\mathrm{~s}, 2 \mathrm{H}), 5.17$ (s, 1H), $5.14(\mathrm{~s}, 1 \mathrm{H}), 3.37$ (s, 3H), 1.40 (s, 18H); MS (ESI) $m / z: 325.2 \quad(\mathrm{M}-\mathrm{H})^{-}$.

2,6-Di-tert-butyl-4-(methoxy( $p$-tolyl)methyl)phenol (3ab): ${ }^{[15]} 63.76 \mathrm{mg}, 75 \%$ yield. A light yellow gum. ${ }^{1} \mathrm{H}$ NMR (500 MHz, Chloroform- $d) \delta: 7.25(\mathrm{~d}, J=7.3 \mathrm{~Hz}$, 2H), 7.14 (d, $J=7.9 \mathrm{~Hz}, 2 \mathrm{H}), 7.11$ (s, 2H), 5.13 (s, 1H), $5.11(\mathrm{~s}, 1 \mathrm{H}), 3.35$ (s, 3H), 2.33 (s, 3H), 1.40 (s, 18H); MS (ESI) $m / z: 339.2(\mathrm{M}-\mathrm{H})^{-}$.

2,6-Di-tert-butyl-4-(methoxy(m-tolyl)methyl)phenol (3ac): ${ }^{[15]} 66.4 \mathrm{mg}, 78 \%$ yield. A light yellow gum. ${ }^{1} \mathrm{H}$ NMR (500 MHz, Chloroform- $d$ ) $\delta: 7.31 \sim 7.26(\mathrm{~m}, 2 \mathrm{H})$, $7.23(\mathrm{dd}, J=7.6,1.6 \mathrm{~Hz}, 1 \mathrm{H}), 7.20$ (s, 2H), 7.12 (d, $J=7.4$ $\mathrm{Hz}, 1 \mathrm{H}), 5.20$ (s, 2H), 3.43 (s, 3H), 2.41 (s, 3H), 1.48 (s, $18 \mathrm{H})$; MS (ESI) $m / z: 339.2(\mathrm{M}-\mathrm{H})^{-}$.

2,6-Di-tert-butyl-4-((3,5-dimethylphenyl)(methoxy)methyl)phenol (3ad): ${ }^{[15]} 65.5 \mathrm{mg}, 74 \%$ yield. A light yellow gum; ${ }^{1} \mathrm{H}$ NMR (500 MHz, Chloroform- $d$ ) $\delta: 7.13$ (s, 2H), 6.99 (s, 2H), $6.87(\mathrm{~s}, 1 \mathrm{H}), 5.12(\mathrm{~s}, 1 \mathrm{H}), 5.08(\mathrm{~s}, 1 \mathrm{H}), 3.35$ (s, 3H), $2.30(\mathrm{~s}, 6 \mathrm{H}), 1.40(\mathrm{~s}, 18 \mathrm{H})$; MS (ESI) $\mathrm{m} / \mathrm{z}: 353.2$ $(\mathrm{M}-\mathrm{H})^{-}$.

2,6-Di-tert-butyl-4-((4-fluorophenyl)(methoxy)methyl)phenol (3ae): ${ }^{[15]} 55.9 \mathrm{mg}, 65 \%$ yield. A white solid. m.p. $100 \sim 102{ }^{\circ} \mathrm{C}$ (Lit. ${ }^{[15]}$ null); ${ }^{1} \mathrm{H}$ NMR $(500 \mathrm{MHz}$, Chloroform- $d$ ) $\delta: 7.32(\mathrm{dd}, J=8.5,5.6 \mathrm{~Hz}, 2 \mathrm{H}), 7.08(\mathrm{~s}, 2 \mathrm{H}), 7.02$ $(\mathrm{t}, J=8.7 \mathrm{~Hz}, 2 \mathrm{H}), 5.16(\mathrm{~s}, 1 \mathrm{H}), 5.15(\mathrm{~s}, 1 \mathrm{H}), 3.35(\mathrm{~s}, 3 \mathrm{H})$, 1.40 (s, 18H); MS (ESI) m/z: $343.0(\mathrm{M}-\mathrm{H})^{-}$.

2,6-Di-tert-butyl-4-((4-chlorophenyl)(methoxy)methyl)phenol (3af): ${ }^{[15]} 72.1 \mathrm{mg}, 80 \%$ yield. A white solid, m.p. $101 \sim 103{ }^{\circ} \mathrm{C}$ (Lit. $\left.{ }^{[15]} 100 \sim 104{ }^{\circ} \mathrm{C}\right) ;{ }^{1} \mathrm{H}$ NMR $(500 \mathrm{MHz}$,
Chloroform- $d$ ) $\delta$ : $7.30(\mathrm{~d}, J=1.1 \mathrm{~Hz}, 4 \mathrm{H}), 7.07$ (s, 2H), $5.17(\mathrm{~s}, 1 \mathrm{H}), 5.13(\mathrm{~s}, 1 \mathrm{H}), 3.35(\mathrm{~s}, 3 \mathrm{H}), 1.40(\mathrm{~s}, 18 \mathrm{H})$; MS (ESI) $m / z: 359.1(\mathrm{M}-\mathrm{H})^{-}$.

2,6-Di-tert-butyl-4-((4-bromophenyl)(methoxy)methyl)phenol (3ag): ${ }^{[15]} 76.8 \mathrm{mg}, 76 \%$ yield. A white solid, m.p. 98 101 ${ }^{\circ} \mathrm{C}$ (Lit. $\left.{ }^{[15]} 98 \sim 101{ }^{\circ} \mathrm{C}\right)$; ${ }^{1} \mathrm{H}$ NMR $(500 \mathrm{MHz}$, Chloroform- $d$ ) $\delta: 7.47 \sim 7.43(\mathrm{~m}, 2 \mathrm{H}), 7.24(\mathrm{~d}, J=8.4 \mathrm{~Hz}$, 2H), 7.07 (s, 2H), $5.17(\mathrm{~s}, 1 \mathrm{H}), 5.11(\mathrm{~s}, 1 \mathrm{H}), 3.35(\mathrm{~s}, 3 \mathrm{H})$, 1.40 (s, 18H); MS (ESI) $m / z: 403.2(\mathrm{M}-\mathrm{H})^{-}$.

2,6-Di-tert-butyl-4-((2-chlorophenyl)(methoxy)methyl)phenol (3ah): ${ }^{[15]} 86.4 \mathrm{mg}, 96 \%$ yield. A white solid, m.p. $95 \sim 97{ }^{\circ} \mathrm{C}$ (Lit. $\left.{ }^{[15]} 96 \sim 98{ }^{\circ} \mathrm{C}\right) ;{ }^{1} \mathrm{H}$ NMR $(500 \mathrm{MHz}$, Chloroform- $d$ ) $\delta: 7.59$ (d, $J=8.1 \mathrm{~Hz}, 2 \mathrm{H}), 7.49$ (d, $J=8.1$ $\mathrm{Hz}, 2 \mathrm{H}), 7.09$ (s, 2H), 5.20 (s, 1H), 5.19 (s, 1H), 3.37 (s, $3 \mathrm{H}), 1.40$ (s, 18H); MS (ESI) $\mathrm{m} / z: 359.0(\mathrm{M}-\mathrm{H})^{-}$.

4-((3,5-Di-tert-butyl-4-hydroxyphenyl)(methoxy)methyl)benzonitrile (3ai): ${ }^{[15]} 86 \mathrm{mg}, 98 \%$ yield. A white solid, m.p. $119 \sim 121{ }^{\circ} \mathrm{C}\left(\right.$ Lit. $\left.^{[15]} 125 \sim 128{ }^{\circ} \mathrm{C}\right)$; ${ }^{1} \mathrm{H}$ NMR $(401$ $\mathrm{MHz}$, Chloroform- $d$ ) $\delta: 7.66 \sim 7.59(\mathrm{~m}, 2 \mathrm{H}), 7.48(\mathrm{~d}, J=$ $8.5 \mathrm{~Hz}, 2 \mathrm{H}), 7.05$ (s, 2H), $5.21(\mathrm{~s}, 1 \mathrm{H}), 5.18$ (s, 1H), 3.37 (s, 3H), 1.40 (s, 18H); MS (ESI) $m / z: 350.1(\mathrm{M}-\mathrm{H})^{-}$.

2,6-Di-tert-butyl-4-(methoxy(4-nitrophenyl)methyl)phenol (3aj): ${ }^{[15]} 90.9 \mathrm{mg}, 98 \%$ yield. A white solid, m.p. 95 $97{ }^{\circ} \mathrm{C}$ (Lit. ${ }^{[15]}$ 98 $\left.100{ }^{\circ} \mathrm{C}\right) ;{ }^{1} \mathrm{H}$ NMR (401 MHz, Chloroform- d) $\delta: 8.20(\mathrm{dd}, J=8.8,1.4 \mathrm{~Hz}, 2 \mathrm{H}), 7.55$ (dd, $J=$ 8.6, $1.4 \mathrm{~Hz}, 2 \mathrm{H}), 7.07$ (d, $J=1.2 \mathrm{~Hz}, 2 \mathrm{H}), 5.24(\mathrm{~s}, 1 \mathrm{H})$, 5.22 (d, $J=1.3 \mathrm{~Hz}, 1 \mathrm{H}), 3.38$ (s, 3H), 1.40 (s, 18H); MS (ESI) $m / z: 369.9(\mathrm{M}-\mathrm{H})^{-}$.

2,6-Di-tert-butyl-4-(methoxy(4-(trifluoromethyl)phenyl)methyl)phenol (3ak): ${ }^{[15]} 73.9 \mathrm{mg}, 75 \%$ yield. A white solid, m.p. $100 \sim 103{ }^{\circ} \mathrm{C}$ (Lit. $\left.{ }^{[15]} 100 \sim 103{ }^{\circ} \mathrm{C}\right) ;{ }^{1} \mathrm{H}$ NMR (500 MHz, Chloroform-d) $\delta: 7.59$ (d, $J=8.1 \mathrm{~Hz}, 2 \mathrm{H}), 7.49$ (d, $J=8.1 \mathrm{~Hz}, 2 \mathrm{H}), 7.09(\mathrm{~s}, 2 \mathrm{H}), 5.20(\mathrm{~s}, 1 \mathrm{H}), 5.18(\mathrm{~s}$, 1H), 3.37 (s, 3H), 1.40 (s, 18H); MS (ESI) m/z: 392.9 (M $-\mathrm{H})^{-}$.

2,6-Di-tert-butyl-4-(methoxy(naphthalen-2-yl)methyl)phenol (3al): ${ }^{[15]} 79.9 \mathrm{mg}, 85 \%$ yield. A yellow solid, m.p. 98 $100{ }^{\circ} \mathrm{C}$ (Lit. ${ }^{[15]} 98 \sim 100{ }^{\circ} \mathrm{C}$ ); ${ }^{1} \mathrm{H}$ NMR $(500 \mathrm{MHz}$, Chloroform- $d) \delta: 7.45 \sim 7.38(\mathrm{~m}, 6 \mathrm{H}), 7.17(\mathrm{~s}, 2 \mathrm{H}), 5.32(\mathrm{~s}$, $1 \mathrm{H}), 5.18(\mathrm{~s}, 1 \mathrm{H}), 3.51$ (s, 3H), 1.48 (d, $J=12.6 \mathrm{~Hz}, 18 \mathrm{H})$; MS (ESI) $m / z: 375.2(\mathrm{M}-\mathrm{H})^{-}$.

tert-Butyl 3-((3,5-di-tert-Butyl-4-hydroxyphenyl)(methoxy)methyl)-1H-indole-1-carboxylate (3am): ${ }^{[15]} 67.5 \mathrm{mg}$, $58 \%$ yield. A yellow solid, m.p. $165 \sim 168{ }^{\circ} \mathrm{C}$ (Lit. ${ }^{[15]}$ 167 $\left.170{ }^{\circ} \mathrm{C}\right) ;{ }^{1} \mathrm{H}$ NMR (500 MHz, Chloroform- $d$ ) $\delta$ : $7.67 \sim 7.62(\mathrm{~m}, 1 \mathrm{H}), 7.39(\mathrm{~s}, 1 \mathrm{H}), 7.31 \sim 7.27(\mathrm{~m}, 1 \mathrm{H})$, $7.26(\mathrm{~s}, 2 \mathrm{H}), 7.21(\mathrm{ddd}, J=8.1,7.2,1.1 \mathrm{~Hz}, 1 \mathrm{H}), 5.40(\mathrm{~s}$, $1 \mathrm{H}), 5.18(\mathrm{~s}, 1 \mathrm{H}), 3.41(\mathrm{~s}, 3 \mathrm{H}), 1.65(\mathrm{~s}, 9 \mathrm{H}), 1.41$ (s, 18H); MS (ESI) $m / z: 464.5(\mathrm{M}-\mathrm{H})^{-}$.

2,6-Di-tert-butyl-4-(ethoxy(phenyl)methyl)phenol (3ba): ${ }^{[15]} 81.6 \mathrm{mg}, 96 \%$ yield. A yellow gum. ${ }^{1} \mathrm{H}$ NMR $(500 \mathrm{MHz}$, Chloroform-d) $\delta: 7.38 \sim 7.29(\mathrm{~m}, 4 \mathrm{H}), 7.22(\mathrm{~d}$, $J=7.2 \mathrm{~Hz}, 1 \mathrm{H}), 7.11(\mathrm{~s}, 2 \mathrm{H}), 5.28(\mathrm{~s}, 1 \mathrm{H}), 5.11(\mathrm{~s}, 1 \mathrm{H})$, $1.39(\mathrm{~s}, 18 \mathrm{H}), 1.26(\mathrm{t}, J=7.0 \mathrm{~Hz}, 3 \mathrm{H})$; MS (ESI) $\mathrm{m} / \mathrm{z}$ : $339.1(\mathrm{M}-\mathrm{H})^{-}$.

2,6-Di-tert-butyl-4-(isopropoxy(phenyl)methyl)phenol (3ca): ${ }^{[15]} 53.1 \mathrm{mg}, 60 \%$ yield. A yellow gum. ${ }^{1} \mathrm{H}$ NMR 
(500 MHz, Chloroform-d) $\delta: 7.38 \sim 7.29$ (m, 4H), 7.23 (d, $J=9.2 \mathrm{~Hz}, 1 \mathrm{H}), 7.11(\mathrm{~s}, 2 \mathrm{H}), 5.41(\mathrm{~s}, 1 \mathrm{H}), 5.11(\mathrm{~s}, 1 \mathrm{H})$, $3.69 \sim 3.61(\mathrm{~m}, 1 \mathrm{H}), 1.39(\mathrm{~s}, 18 \mathrm{H}), 1.22(\mathrm{dd}, J=10.7$, $6.1 \mathrm{~Hz}, 6 \mathrm{H})$; MS (ESI) $m / z: 353.2(\mathrm{M}-\mathrm{H})^{-}$.

4-(Butoxy(phenyl)methyl)-2,6-di-tert-butylphenol (3da): ${ }^{[15]} 67.2 \mathrm{mg}, 73 \%$ yield. A yellow gum. ${ }^{1} \mathrm{H} \mathrm{NMR}$ (500 MHz, Chloroform- $d$ ) $\delta: 7.34$ (dq, $J=14.2,6.6 \mathrm{~Hz}$, $5 \mathrm{H}), 7.11(\mathrm{~s}, 2 \mathrm{H}), 5.26(\mathrm{~s}, 1 \mathrm{H}), 5.11(\mathrm{~s}, 1 \mathrm{H}), 3.44(\mathrm{~s}, 2 \mathrm{H})$, $1.67 \sim 1.60(\mathrm{~m}, 2 \mathrm{H}), 1.57(\mathrm{~d}, J=7.9 \mathrm{~Hz}, 2 \mathrm{H}), 1.39(\mathrm{~s}$, $18 \mathrm{H}), 0.90$ (q, $J=6.7,5.6 \mathrm{~Hz}, 3 \mathrm{H}$ ); MS (ESI) $m / z: 367.0$ $(\mathrm{M}-\mathrm{H})^{-}$.

2,6-Di-tert-butyl-4-((cyclohexyloxy)(phenyl)methyl)phenol (3ea): ${ }^{[15]} 61.1 \mathrm{mg}, 62 \%$ yield. A white solid, m.p. 105 $107{ }^{\circ} \mathrm{C}$ (Lit. $\left.{ }^{[15]} 108 \sim 110{ }^{\circ} \mathrm{C}\right)$; ${ }^{1} \mathrm{H}$ NMR $(500 \mathrm{MHz}$, Chloroform- $d) \delta: 7.36 \sim 7.29(\mathrm{~m}, 4 \mathrm{H}), 7.26 \sim 7.17(\mathrm{~m}, 1 \mathrm{H})$, 7.09 (s, 2H), 5.48 (s, 1H), $5.10(\mathrm{~s}, 1 \mathrm{H}), 3.34$ (ddd, $J=9.3$, $5.5,3.9 \mathrm{~Hz}, 1 \mathrm{H}), 2.01 \sim 1.88(\mathrm{~m}, 2 \mathrm{H}), 1.79 \sim 1.71(\mathrm{~m}, 2 \mathrm{H})$, $1.63 \sim 1.42(\mathrm{~m}, 6 \mathrm{H}), 1.39(\mathrm{~s}, 18 \mathrm{H})$; MS (ESI) $m / z: 393.0$ $(\mathrm{M}-\mathrm{H})^{-}$.

2,6-Di-tert-butyl-4-(((2-methylallyl)oxy)(phenyl)methyl)-phenol (3fa): $66.8 \mathrm{mg}, 73 \%$ yield. A yellow gum. ${ }^{1} \mathrm{H}$ NMR (500 MHz, Chloroform- $d$ ) $\delta: 7.39 \sim 7.31(\mathrm{~m}, 4 \mathrm{H})$, $7.27 \sim 7.20(\mathrm{~m}, 1 \mathrm{H}), 7.12(\mathrm{~s}, 2 \mathrm{H}), 5.32(\mathrm{~s}, 1 \mathrm{H}), 5.12(\mathrm{~s}$, $1 \mathrm{H}), 5.02 \sim 4.98(\mathrm{~m}, 1 \mathrm{H}), 4.93 \sim 4.89(\mathrm{~m}, 1 \mathrm{H}), 3.94 \sim 3.84$ (m, 2H), 1.79 (s, 3H), 1.39 (s, 18H); ${ }^{13} \mathrm{C}$ NMR (101 MHz, Chloroform- $d$ ) $\delta$ : 153.24, 142.64 (d, $J=15.4 \mathrm{~Hz}), 135.66$, $132.83,128.41,127.31,127.21,124.19,112.28,82.94$, 72.66, 34.47, 30.42, 19.94); MS (ESI) $m / z: 365.0$. HRMS (ESI) calcd for $\mathrm{C}_{25} \mathrm{H}_{34} \mathrm{O}_{2}(\mathrm{M}-\mathrm{H})^{-}$366.5450, found 365.24854

4-((Benzyloxy)(phenyl)methyl)-2,6-di-tert-butylphenol (3ga): ${ }^{[15]} 74.4 \mathrm{mg}, 74 \%$ yield. A yellow gum. ${ }^{1} \mathrm{H} \mathrm{NMR}$ (500 MHz, Chloroform-d) $\delta: 7.44 \sim 7.32(\mathrm{~m}, 10 \mathrm{H}), 7.12(\mathrm{~s}$, 2H), $5.36(\mathrm{~s}, 1 \mathrm{H}), 5.14(\mathrm{~s}, 1 \mathrm{H}), 4.54(\mathrm{dd}, J=7.9,4.2 \mathrm{~Hz}$, 2H), 1.39 (s, 18H); MS (ESI) m/z: $401.2(\mathrm{M}-\mathrm{H})^{-}$.

Supporting Information ${ }^{1} \mathrm{H}$ NMR spectra and MS for compounds 3aa $\sim$ 3am, 3ba $\sim$ 3ga, Crystallographic data and structure refinement parameters of [Bi]. The Supporting Information is available free of charge via the Internet at http://sioc-journal.cn/.

\section{References}

[1] (a) Peter, M. G. Angew. Chem. Int. Ed. 1989, 28, 555.

(b) Itoh, T. Prog. Polym. Sci. 2001, 26, 1019.

(c) Toteva, M. M.; Richard, J. P. Adv. Phys. Org. Chem. 2011, 45,
39.

[2] (a) Takao, K.; Sasaki, T.; Kozaki, T.; Yanagisawa, Y.; Tadano, K.; Kawashima, A.; Shinonaga, H. Org. Lett. 2001, 3, 4291.

(b) Jansen, R.; Gerth, K.; Steinmetz, H.; Reinecke, S.; Kessler, W.; Kirschning, A.; Müller, R. Chem.-Eur. J. 2011, 17, 7739.

(c) Smith, A. B.; Mesaros, E. F.; Meyer, E. A. J. Am. Chem. Soc. 2006, 128,5292 .

(d) Kupchan, S. M.; Karim, A.; Marcks, C. J. Am. Chem. Soc. 1968, 90, 5923.

[3] (a) Lima, C. G. S.; Pauli, F. P.; Costa, D. C. S.; de Souza, A. S.; Forezi, L. S. M.; Ferreira, V. F.; da Silva, F. de C. Eur. J. Org. Chem. 2020, 18, 2650.

(b) Wang, J.-Y.; Hao, W.-J.; Tu, S.-J.; Jiang, B. Org. Chem. Front. 2020, 7,1743 .

[4] Chu, W. D.; Zhang, L. F.; Bao, X.; Zhao, X. H.; Zeng, C.; Du, J.; Zhang, Y. G. B. F.; Wang, X.; Ma, X. Y.; Fan, C. A. Angew. Chem. Int. Ed. 2013, 52, 9229.

[5] Caruana, L.; Kniep, F.; Johansen, T. K.; Poulsen, P. H.; Jorgensen, K. A. J. Am. Chem. Soc. 2014, 136, 15929.

[6] Lou, Y. Z.; Cao, P.; Jia, T.; Zhang, Y. L.; Wang, M.; Liao, J. Angew. Chem. Int. Ed. 2015, 54, 12134.

[7] Dong, N.; Zhang, Z. P.; Xue, X. S.; Li, X.; Cheng, J. P. Angew. Chem. Int. Ed. 2016, 55, 1460 .

[8] Jarava-Barrera, C.; Parra, A.; Lopez, A.; Cruz-Acosta, F.; Collado-Sanz, D.; Cardenas, D. J.; Tortosa, M. ACS Catal. 2016, 6, 442.

[9] Huang, G. B.; Huang, W. H.; Guo, J.; Xu, D. L.; Qu, X. C.; Zhai, P. H.; Zheng, X. H.; Weng, J.; Lu, G. Adv. Synth. Catal. 2019, 361, 1241.

[10] He, F. S.; Jin, J. H.; Yang, Z. T.; Yu, X. X.; Fossey, J. S.; Deng, W. P. ACS Catal. 2016, 6, 652 .

[11] Cheng, Y. Y.; Fang, Z. Q.; Jia, Y. W.; Lu, Z. Y.; Li, W. J.; Li, P. F. RSC Adv. 2019, 9, 24212.

[12] Wang, D.; Song, Z. F.; Wang, W. J.; Xu, T. Org. Lett. 2019, 21, 3963.

[13] Zhao, K.; Zhi, Y.; Wang, A.; Enders, D. ACS Catal. 2016, 6, 657.

[14] (a) Liu, T.; Liu, J.; Xia, S.; Meng, J.; Shen, X.; Zhu, X.; Chen, W.; Sun, C.; Cheng, F. ACS Omega 2018, 3, 1409. (b) Jadhav, A. S.; Anand, R. V. Org. Biomol. Chem. 2017, 15, 56.

[15] Yu, J.; Chen, S.; Liu, K.; Yuan, L.; Zhao, Y.; Chai, Z.; Mei, L. Tetrahedron Lett. 2020, 61(27), 152076.

[16] (a) Xie, K. X.; Zhang, Z. P.; Li, X. Org. Lett. 2017, 19, 6708. (b) Goswami, P.; Anand, R. V. ChemistrySelect 2016, 1(10), 2556

[17] (a) Lu, H.; Wu, R.; Cheng, H.; Nie, S.; Tang, Y.; Gao, Y.; Luo, Z. Synthesis 2015, 47, 1447

(b) Lu, H. F.; Sun, L. L.; Le, W. J.; Yang, F. F.; Zhou, J. T.; Gao, Y. H. Tetrahedron Lett. 2012, 53, 4267.

(c) Ni, S.; Shen, W.; Gao, Y.; Tang, Y.; Zhang, X.; Gu, X.; Lu, H. Chin. J. Org. Chem. 2015, 35, 2393 (in Chinese)

(聂士鹏, 沈薇, 高玉华, 唐演, 张翔, 谷晓玉, 陆鸿飞, 有机化 学, 2015, 35, 2393.)

[18] Lu, H.; Zhou, J.; Cheng, H.; Sun, L.; Yang, F.; Wu, R.; Gao, Y.; Luo, Z. Tetrahedron 2013, 69, 11174.

[19] Zhang, X.; Gu, X.; Gao, Y.; Nie, S.; Lu, H. Appl. Organomet. Chem. 2017, 31, 1

[20] Liang, X.; Xu, H.; Li, H.; Chen, L.; Lu, H. Eur. J. Org. Chem. 2020, 2,217 .

[21] Abrams, P.; Freeman, R.; Anderstrom, C.; Mattiasson, A. Br. J Urol. $1998,81,801$. 